Nov. 20

Krause, Hamilton U. Paintings by foreign and American artists. Davis and Harvey Galleries. 37 p., 175 lots.

Nov. 27

Heysinger, Dr. L. W. and others. Color engravings after G. Morland and by F. Bartolozzi. Etchings, porcelain, paintings. Henkels (no. 870) 18 p. 195 lots.

1902 April 24

Hall, Thomas William. Engravings, etchings, water colors, paintings, etc. Henkels (no. 878) 29 p., illus. 449 lots. Priced.

Dec. 19

Rare engraved portraits of Washington and other American notables. American naval battles. Early American views. Colored caricatures, ete. Henkels (no. 888) 26 p. 246 lots.

\section{JCL ACADEMIC YEAR INSTITUTE}

Recruitment assistance is being sought by Appalachian State University to find participants for the academic year institute for Junior College Librarians which has been funded under Title IIB, HEA. Designed to develop twenty new professionals with strength in the Learning Resource concept and familiarize them with the philosophy of the community junior college, the session will run from September 1969-July 1970. The program leads to the M.A. degree in Library Science. Applicants must hold a bachelor's degree and have completed at least nine quarter hours (six semester hours) of basic undergraduate work in $\mathrm{Li}$ brary Science. The stipend for each participant will be $\$ 75$ a week plus $\$ 15$ a week for each dependent. Most fees will be paid from the grant. Applications for admission must be on file by June 1, 1969.

In the summer of 1970 , twenty additional participants will join the group. Only full-time community junior college librarians are eligible to apply for this phase of the institute, during which a series of "mini-courses" designed to familiarize students with current trends and practices in automation, multimedia utilizations, and management techniques will be presented by visiting lecturers and the Appalachian staff. Stipends are the same as for the earlier part of the program. Applications for admission to this portion must be on file by June 1, 1970 .

For information and application forms, write to Professor Eunice Query, Director, Academic Year Institute for Junior College Librarians,
Appalachian State University, Boone, North Carolina 28607.

\section{ABPC/RTSD PRECONFERENCE}

"New Dimensions in Acquisitions" will be the theme of a $2 \frac{1}{2}$ day Institute June 19 through June 21,1969 , to be held prior to the annual conference of ALA in Atlantic City. The Sponsors of this Institute is the American Book Publishers Council and the Resources and Technical Services Division Joint Committee of the American Library Association.

Innovative approaches to the solutions of library acquisition problems will be emphasized through both traditional print material and the newer non-print materials. Among traditional problems covered in the Institute sessions will be the out-of-print market, periodical subscriptions, gifts and exchanges, and the purchase of paperbacks. Newly emerging techniques for purchasing, such as advance copy plans, blanket orders, and centralized acquisitions will be presented along with modern acquisition techniques using computer processing, the standard book number, and other aspects of scientific management.

The opening address will be by James C. Worthy of the management consultant firm of Cresap, McCormick and Paget. Mr. Worthy's topic will be "Scientific Management" stressing the need for efficient and economical procedures, research experimentation, and testing of acquisitions systems. Mrs. Elizabeth Rodell of Rice University, for seven years executive secretary of the Resources and Technical Services Division, will be the banquet speaker. Her topic "Performance Goals for the Acquisitions Process."

To register, send name and address, with or without the official application blank, with the registration fee of $\$ 41.00$, to ABPC-RTSD Preconference Institute, American Library Association, 50 East Huron Street, Chicago, Illinois 60611. Please make checks payable to the American Library Association. The Institute is limited to 500 attendees.

The Institute will be held in the Dennis Hotel, Atlantic City. For hotel reservations, use the housing form in the January $1969 A L A$ Bulletin. Room reservations will be honored in the block space only until May 1. Request housing in the Lombardy, Mt. Royal or Traymore hotels where space is being reserved for attendees at this institute. Include the statement that you will be attending the ABPCRTSD Preconference Institute. The registration fee covers the costs of luncheons on Thursday and Friday and the banquet Friclay evening. 